Article

\title{
Bridges Don't Make Themselves: Using Community-Based Theater to Reshape Relationships: Rethinking the Idea of Abundance in ABCD
}

\author{
Zechariah Lange (D) \\ Department of Urban and Regional Planning, Florida State University, Tallahassee, FL 32306, USA; \\ zj113@my.fsu.edu
}

Received: 29 May 2020; Accepted: 19 July 2020; Published: 21 July 2020

\begin{abstract}
Community-based theater has a variety of manifestations, and the plurality with which these manifestations are occurring is increasing. As such, the diversity and complexity derived from these social sites of public engagement requires further understanding. This article is based upon a multi-case study of two community-based theaters: one in Middle Appalachia, and the other on the Gulf Coast of Florida. Together these sites of performative expression are acting as social interventions for differing reasons within their respective contexts. Through intensive and communicative processes, the theaters provide examples of how co-created performances at the community level simultaneously catalyze relationships and alter how relationships are experienced to engage community members in discussion and performances. As a complex behavioral interaction, the two theaters simultaneously manifest dimensions of 'abundance', as well as expand upon normative conceptions of asset-based community development. Through process and contextual modeling, the work provides in-depth exploration to these interpersonal endeavors to assist in how socio-cultural differences as well as narrative reconstruction co-join to enact the individuality of identity across working groups as an overall discursive process.
\end{abstract}

Keywords: public engagement; interdependency; relationality; community-based theater; asset-based community development

\section{Introduction}

The transition from potential or imagined to actual in socio-cultural contexts implies the continuous construction of communication modalities, and the reinstitution of interpretation into action. The construction or co-construction of a progressive idea at any scale, sector, geographic area, or situation is nested in/between people. No idea in nested and entangled social environments, from the original imagination to its realized construction, happens in detached isolation, or is separate from the methods used in the imagining or physicalizing [1,2]. Hutchins [2] states that "human cognition is always situated in a complex sociocultural world and cannot be unaffected by it" (p. xiii). Imaginings of a future that either diverges from or builds upon the present requires continuous visualization, reflection, relationality, and action [3]. As such, if persons seek localized change within their respective lives and shared spaces, then desired change is inseparable from history and culture.

Speaking from a backdrop of crumbling neighborhoods, economies, political systems, and the resultant exacerbation of cultural fragmentation, John McKnight and Peter Block have long advocated for asset-based community development to address community needs (ABCD). McKnight and Block [4] describe a potential for human collaboration that transitions away from the isolating and inflammatory behavior of economic consumptive scarcity for the construction of relational 'abundance'. Their perspective, in short, is that happiness and freedom cannot be solely purchased, and that social 
capital has largely been eroded due to economic inequality and cultural fragmentation. McKnight's and Block's conception of 'abundance', which differentiates from material abundance, is built upon human relationships that are inspired by a shared dissatisfaction with the world out of a belief that this is a time of profound institutional, governmental, and economic failure [5]. Meaning, for better or worse, that McKnight and Block support developing a subversive (and partially utopian) but socially collaborative response to the current ills of Western society. However, the methods, theories, and perspectives proposed speak little to none beyond class on such critical issues as race, gender, sexuality, age, ability, and crucial components pertaining to identity.

ABCD was originally introduced by Kretzmann and McKnight [6] as a potential method of engaged social collaboration for citizens to create and share co-constructed opportunities at the neighborhood and community scales. ABCD, since its inception, is perhaps best described as a form of perception, albeit a normatively white perception, that imagines creative potential within socio-cultural, economic, political, and environmental constraints. In essence, ABCD asks, how do day-to-day citizens create opportunities to help address needs as well as progress beyond them? ABCD transitions away from need or deficit-based community development models but does not entirely exclude their theoretical value in addressing inequalities [7]. ABCD, within these informal contexts of differential social movements, has been linked to backyard activists [8] and has been substantially investigated for efficacious public health behaviors such as social support [9]. Nevertheless, there are other spaces, processes, and aspects of ABCD that can be operationalized through community-based theater (CBT) and that fall outside of the usual Neoliberal entrapments [10].

One of the core tenets of ABCD, as outlined by McKnight and Block [4], is the transition from economic scarcity towards co-created relational 'abundance' at the neighborhood scale. Building on this perspective, CBT has been suggested to be a cost-efficient praxis through which socio-cultural change can occur through constructed relationships and performances in a localized context [11,12]. Further, it has been suggested that the work of theater making in a public sphere, not just the aesthetic performances themselves, aids in meaning-making and supporting individuals in learning about themselves and each other as a discursive, dialogical, and experiential practice [13-15]. Put succinctly, the researched CBTs are places of shared responsibility and interdependence for the generation of performative productions for a public audience. In general however, CBTs are intentionally driven and, as a method, offer a conduit for manifesting multifaceted messages, meanings, and actions which can include social mobilization, political agency, the preservation of cultural heritage, collective cultural expression, and more [11,12,16-18].

This article was generated through months of collaborative work with two community-based theaters and grounded in two full theater production cycles (one for each theater). Each CBT is situated in rural and impoverished counties in the American south. One CBT is situated along the Florida Gulf Coast, and the other in Middle Appalachia. The theaters are profoundly different regarding praxis because each theater has differing reasons for their existence, but each seek community change based in the 'collective' cultural contexts of the counties. As a point of clarity, the use of the word 'collective' is synonymous with differences within the active exchange of socio-cultural lives, identities, and experiences that occurred within these CBTs. Here, 'collective' is a collaborative process happening across differences. The environments of the researched CBTs can be likened to complex adaptive systems [19] that contain myriads of identities, histories, beliefs, and perspectives that serve as fertile soil for subjunctive spatial expression, relationality, and learning between people and audiences [11,20]. In this article, the research focuses on the social dynamics of space and place creation that serve pedagogical functions for the catalyzation and reconstitution of 'community' as a discursive process [21]. In other words, this work asks the following: how do these two theaters within their situated praxes both create spaces and functions of asset-based community development, but also spaces and functions of expressive change for participants and audiences? 


\section{Constructivist Embodied Methodology}

CBTs create unique lived performative experiences between citizens as their form of identity and community change in an overarching narrative and cultural construction. As such, this research had to be involved with and entangled/situated in the social milieu to tap into these experiential waters, and to ground the abstractionism that often undergirds such concepts as 'change', 'community', 'identity', and 'collective' [22]. As stated by Young [23],

"I argue that the ideal of community exhibits a totalizing impulse and denies difference in two primary ways. First, it denies the difference within and between subjects. Second, in privileging face to face relations it seeks a model of social relations that are not mediated by space and time distancing. In radically opposing the inauthentic social relations of alienated society with the authentic social relations of community, moreover, it detemporalizes the process of social change into a static before and after structure." (p. 5)

In short, the understanding of socio-cultural processes derived from the work performed was most incarnate in the navigation of constantly shifting happenings and interactions that mandated deeper engagement with others as part of the ethical and respectful investigation of differences (and personal boundaries) which are built upon temporality, lived experiences, and everchanging meanings. The dichotomies and tensions between individualism and community are necessary as they currently stand to spark progression beyond the trappings of idealism and essentialism [21]. As such, the methodological requirements, and the resultant emotional dexterity necessary to perform in these entangled environments, were thus unique for each theater [24].

Despite intensive labor put forth towards the relational and participatory, I still extensively documented participatory observations through memos/journals (150+ pages), and seven hours of personal audio files. These documenting processes occurred after each direct experience in the field, and would cover interpersonal experiences, experiences shared with me by participants, direct performance work, organizational frameworks, and the cultural dimensions of the participants and communities. I would routinely revisit, reorganize, and reread these extensive compilations. Further, I accumulated approximately $25 \mathrm{~h}$ of interviews with 31 participants across both research sites after the creation and enactment of performances. These interviews were transcribed and were used extensively as reference material. The interview questions and discussions were grounded in shared experiences in the communities, as well as in open exploration of salient topics pertaining to the participants and theaters. The interviews were positioned for sense and meaning-making of the experiences had during the theater cycles in both communities. These interviews were instrumental in providing an in-depth exploration between researcher and community members that systematically, and from diverse perspectives, reflected upon the theater productions and the theaters' places in the counties.

In person, at Sitting in the Shade Together Theater (SSTT), I spent approximately six months assisting, building, and acting in performances. At Appalachian Theater (AT), I spent approximately three intensive weeks assisting in performance design and relationship building across participants, leadership, and partnered non-profits. The difference in time spent at each theater is due to the length of performance cycles. Appalachian Theater has very short, but nonetheless rigorous, production cycles in the creation of performances. Productions at Sitting in the Shade Together Theater generally can take three to four months to complete due to the utilization of scripts, set design/construction, and rehearsals.

The process of data analysis took many forms. Over the weeks and months of working with the community-based theaters, there were enormous discursive efforts made during performance construction and enactments. These relational and extensively conversational efforts covered such things as stage design, the artistic expression of scenes, the translation of scenes to audience/communities, etc. Performative dimensions such as these predominantly focused on the interpretive elements of performances, and the creation of identifiable themes and attributes that 
were salient to the local communities. Further, the interpersonal interactions between myself and others changed over time as memory and experiences were shared and created. In other words, these interpretive and performative discursive actions were a way of deepening and challenging the observed.

However, the research narratives became most elucidated during the writing phase of the work [25]. As I began to position this work in relations to available and related literature, narratives were thus formulated. As a part of this process, all compiled documented data and direct experiential knowledge took shape in relations to the work done with the theaters, and thus allowed for the interpretive theorization to be situated [26]. The research narratives were an act of constant reconstruction, particularly relating to the reconstitution of meanings for the creation of clarity pertaining to performative, communal, and cultural change. Meaning that as literatures, interviews, and compiled participant-observation data were continuously interrogated, emergent contributions were produced as an act of analysis itself [26]. Most simply put, the data collected, far from being disembodied, was interpreted during the writing process through an iterative cycle that can be thus summarized: data collection; comparison of data and preemptive interpretation with existing literature to begin uncovering themes; discussion with participants and theater leaderships in in-depth conversations regarding these themes; reinterpretation and documentation of emerging understandings; implementation of new understandings; and, finally, reconsulting those at the research sites to corroborate and add further meaning to the thus generated layers of meaning and themes.

\section{Relearning to Learn}

Much of the existing community development literature often swirls with language supporting the supposed harmony of community [22,23,27-30]. This article argues that conceptions of community in the normative sense, as well as the concepts of 'the structure of feeling', or 'the structure of belonging', [31] can at times replicate and uphold ideologies of privilege and authenticity due to their isometric underpinnings that blanket the real inequalities between people as a function of power [28,32,33]. In other words, the desire for social transformation as an ideal [31] can reduce important historically derived socio-cultural differences in the push for a synthesis of social identity that can result in erasure, determinacy, and essentialism [21,34].

From the perspective of this paper, the usual linkage of commonality that constitutes normative definitions of community, or the often theoretically dubious transformative community, is not what formed working relationality within the theaters [35]. In essence, the place and space of community-based theater is not enough to signify a 'community.' To do so would be tantamount to the idealization of the theaters and would thus reduce a sense of ethical criticality necessary to investigate such things as cultural production, reproduction, and placemaking [26,36]. The work of this research sought the inquiry of dialogue creation, the activation of working relationships, the deepening of interpersonal trust, and the open exploration of lived experiences both in and out of the theaters. In other words, the places, spaces, processes, and experiences that drive experiential learning in affective environments can be explored more deeply, for practice and theory, regarding public engagement [37-39].

Performative pedagogy in CBT is thought of as an experiential, embodied, and collaborative process of unveiling the background of normative socio-cultural existence, an intentional unraveling of interpersonal guardedness and ideologies through concerted participatory experiences that helps us to see what's going on around us as well as within us ... CBT has a way of 'shaking us awake' by challenging held assumptions, and then asking us to communicatively reinstitute these experiences within our webs of reality with others. The closer one gets to the unspoken cultural realities that disrupt personal lives, the more potential there is in ameliorating such realities.

"Cultural studies has always been propelled by its desire to construct possibilities, both immediate and imaginary, out of its historical circumstances. It has no pretensions to totality or universality; it seeks only to give us a better understanding of where we are so that we 
can get somewhere else (some place, we hope, that is better-based on more just principles of equality and the distribution of wealth and power." [40] (p. 415)

During the closing remarks of the last performance, the President of AT helped to take usually personal matters that reside in the privacy of families, and make them public for shared understanding and discourse to suggest that all can help one another during times of need regardless of blood ties:

"On this stage today, you have witnessed stories beginning with birth, family hardships, fun times, laughter all the way through [to] the death of a grandfather. These are all part of life and part of most of your families. Many of you could tell the same stories. What is most important and evident in each scene is the love of family can help us overcome many things that come our way."

The pedagogical process of learning across socio-cultural differences is a situational discussion based upon complex personal and interpersonal identity, and grounded frameworks derived from these environments must be ethically crafted so as to not speak for those speaking. Nor should thinking models, which inevitably reduce the emotive potential of learning, experiencing, and being, be the goal considering the grassroots nature of these theaters [41]. However, we as practitioners, researchers, and students seek tangible elements of projects worthy of insight into behavioral and cultural change when seeking community development strategies [22].

The social collisions between methods, environments, and participants are a ripe area of learning when attempting to understand the situational experiences generated through collaborative work [35]. "If people don't talk about it, we didn't do a good enough job" (President of AT, personal communication). Pedagogy and the praxes of the CBTs are processes of collaborative interdependency which affirm and highlight differences through an acknowledged situatedness within a shared space [18]. Horton and Freire [42] believe that education is more than being told what to think and is more akin to helping individuals see/feel with their own eyes and bodies. This is a fundamental shift away from hierarchically driven education based in authority and expertise. Here, experiential learning and CBT adjoin themselves with ABCD through the co-investigation of meaning-making roles through enacted theater productions in the pursuit of community change. In other words, people discover things about themselves, each other, and their worlds through collaborative productions that they themselves voluntarily build and invest in, and such instantiations of intention and action constitute physicalized cultural change [36].

If we consider $\mathrm{ABCD}$ and $\mathrm{CBT}$ as adaptive forms of human behavior to unsatisfactory socio-cultural and socio-economic conditions, then what happens in the process of theater making to actualize desired changes? Each theater, from both counties, are based within a vulnerable openness to public participation to enhance the opportunity to discuss lived experiences in their respective counties. Participation is purely voluntary in the theaters, which permits a genuine sincerity, intentionality, and directness-not authenticity-to emerge through and between people in the process of placemaking during the creation and performance of the productions.

"Why can't we mix and mingle and understand each other better so that this can be a better place? Some of the people are willing to do that. Some of the people are afraid to do that. Some people lack the tools to do that. So, why not open up something that just says 'Hey, we are doing something tonight. Why don't you come in, check it out? And just be a part of it. Doesn't matter who you are. It doesn't matter what you believe. You could walk away mad if you want, but you were there. As long as you tell me what your madness is stemming from'" (President of SSTT, personal communication)

Meaning that it is not through hierarchical decision-making, strategic planning, or idealistic platitudes that change occurs. "Letting go of technical rationality frees us to make space for sensory imagery" [43] (p. 66). It is within an inherently unstable system that the method of theater making as a 
facilitative and meaning - making process occurs and further becomes a grounding dialogic space of cultural interaction and interpretation in the sea of voices. (Table 1)

Table 1. A Brief Comparison of Asset-Based Community Development (ABCD) and Community-Based Theater.

\begin{tabular}{|c|c|c|}
\hline & Asset-Based Community Development & Community-Based Theater \\
\hline Orientation/Intention & $\begin{array}{l}\text { Often used as a theoretical form of guidance and } \\
\text { can be methodologically prescribed to engage } \\
\text { individuals in forms of communion and } \\
\text { agreement for co-created action [44]. } \\
\text { Often manifested as a practice of relational } \\
\text { socio-cultural engagement to produce, share, and } \\
\text { grow community resources and } \\
\text { opportunities [45]. }\end{array}$ & $\begin{array}{c}\text { Is a 'bottom-up' intervention that is highly } \\
\text { collaborative, participatory, and inclusive. } \\
\text { Is communicatively based within social } \\
\text { interaction to co-create culturally salient } \\
\text { performances [46]. }\end{array}$ \\
\hline Lead Organizations & $\begin{array}{l}\text { Can be instrumented through neighborhood } \\
\text { associations, non-profits/NGOs, governmental } \\
\text { and planning institutions, as well as through } \\
\text { individuals, and is thus highly collaborative and } \\
\text { boundary-crossing }[47,48] \text {. }\end{array}$ & $\begin{array}{c}\text { Is often housed and organized within } \\
\text { non-profit organizations, non-governmental } \\
\text { agencies, as well as through informal social } \\
\text { relationships [18]. }\end{array}$ \\
\hline Purpose & $\begin{array}{c}\text { Often confrontational and resistant towards the } \\
\text { Neoliberal state, as well as towards overt forms } \\
\text { of cultural imperialism, oppression, } \\
\text { disenfranchisement, and socio-cultural } \\
\text { fragmentation [49]. }\end{array}$ & $\begin{array}{l}\text { Through the 'work' of CBT, active efforts } \\
\text { are relationally made to build relationships } \\
\text { towards the end of continuing participation } \\
\text { over time and in an overall orientation of } \\
\text { placemaking [50]. }\end{array}$ \\
\hline Product/Outputs & $\begin{array}{l}\text { The creation and organization of community } \\
\text { resources and relationships between individuals, } \\
\text { institutions, organizations, and agencies [51]. }\end{array}$ & $\begin{array}{l}\text { As a cultural apparatus which manifests } \\
\text { through co-created performances and } \\
\text { participations, active work is sustained } \\
\text { through CBT to challenge and reconstruct } \\
\text { corrosive cultural narratives [52]. }\end{array}$ \\
\hline
\end{tabular}

\section{Emergent Community Ritual-Expanding the Definition of Blood in Appalachia}

It was New Years, and the leaders of Appalachian Theater were in a hand-built cabin without electricity at the base of a rocky and wooded hill to celebrate. Fire provided the only light and heat. Just outside the cabin is a creek, and just beyond that is a 200-year-old tobacco farm. Farms in this county often are located in what was once the older sections of creeks that build sediment, soil, and level elevation through fluvial processes. The theater President's husband spoke and discussed his love of nature, particularly its ability to evoke humility. The ability for nature to generously remind us that life is short, fleeting, but also precious (a belief that helped propel the theater into existence and action). The shared properties surrounding the farm all belonged to one family, and all are powered by an old shared natural gas well drilled deep in the rock. This is a common occurrence of sharing and self-reliance that has been practiced for over a century. The theater's leadership (the board members), a local musician/crafter/theater participant, and I spoke much on the theater that night.

The President and I have previously spoken privately on many sensitive topics relating to the county such as race, class, sexuality, and gender. These topics are not easily broached publicly in Appalachia, and I was curious to ask about the challenges of creating belonging through theater work because of Appalachia's adherence to heteronormative gender roles (the theater itself was started by four women, one of which a woman of color). "Had we tried to stage those sensitive issues right off the bat, it would not have worked ... we would've been dead in the water. It's like we've eased the door open" (President of AT, personal communication). While we were eating and conversing in the cabin, the President announced to the whole of the group, without warning, "Zech wants to talk about race!" And so we did, particularly about the difficulties of bridging racial divides despite unyielding labor being put forth to do so by the theater-the wounds regarding race, as they are in most Southern counties/states, are very old, complex, and enduring. I wanted to know what kind of community was being created. Despite the stimulating discussion about how their theater fits in the swirl of sensitive cultural topics in the county, and particularly its history, that was not the key moment of the night. It was when the local musician, who has lived in the county for 70 years and who raised herself and her 
children from nothing with only sheer will, sang her own song whilst playing the mandolin describing the collapse of a coal mine in the county that claimed the lives of more than 30 men.

It was a song honoring the men who would no longer return home with soot covered faces. The mines claimed their lives after a lifetime of devotion. Coal, despite its destructive capacity on people and nature, is all many families had to put food on the table. There is no romanticism here, and nor does the theater preach idealism; rather, it is a gritty pragmatism that seeks to create belonging out of the rugged and often brutal history of the county. Mountain County has seen and experienced much, with legacies of leaving behind those who were not born with a silver spoon in their hand to grind out a life. A host of ills have been forced upon it which includes state coercion, political corruption, brutal generational feuds, predatory extractive industries (slavery, salt, coal, forestry), the end of family subsistence farms, and now the end of coal. Coal was the last remaining economic lifeline the county had. Every year, droves of people abandon the county for employment and education opportunities elsewhere. Those who remain, and that choose to place their courage in change, grapple with crippling poverty annually exceeding $40 \%$ and an opioid crisis. "Zech, we have been beaten down as hillbillies" (President of AT, personal communication). Collaboration and social support in this county quite literally save lives.

These are the realities of the performed stories in AT. Every scene is improvised based upon true stories from the county's inhabitants, and many of the story's owners are involved in the production process. These stories are actively and respectfully recruited by the theater's leadership, and those who own the stories often sit in the audience to see their own memories enacted. The identities of those who own the stories are never shared out of a respect for privacy. AT's performances are improvised, and there are no lines to memorize. Further, AT uses the few stages in the county, usually at local schools, or their historic downtown park, because they do not have a house to call their own. Close cultivated relationships between $\mathrm{AT}^{\prime}$ 's leadership and other community leaders are used to leverage these resources for performances. The actors are given the rough frameworks of the stories and are asked to create the scenes from their interpretations of the stories. The lack of scriptural expectation allows participants to interpret scenes to create the performance, but also calls upon them to take responsibility for the stories' owners. "You want to give their story justice ... You don't know what people have gone through" (AT theater participant, personal communication).

Imagine a group of strangers collaboratively learning to sing 'Down by the River to Pray' live in the local high school auditorium. The actors in synchronized movement surround the audience in vocal ambiance to bring everyone into communion. "Down to the River to Pray" sang live memorialized the county's past to create a shared, and understood, acknowledgment between the theater and local audience through the local sanctuary of Christian faith. Church is the main focal point for personal connection between the people living in the rugged Mountain County. As such, the narrative themes of prayer, song, and stories of trauma, abuse, loss, but also love and laughter, became elevated to a new plane of shared affective experience through theater making. Further, the narrative themes of the performance are coded and described on stage through actors and props to elicit images of local places, jobs, clothing, mannerisms, language, food, and more to bring a sense of familiarity to the participants and audience members. In all, five generations performed in one production in the pursuit of renewal and overcoming hardship through personal connection.

\section{Resetting the Tone-Who Are the Insiders of a Community in the Old South?}

I rejoined the Director and President of SSTT after we just went through an exhausting rehearsal. I looked up from my cinderblock that served as a makeshift seat, our usual decompression area along the backside of the building, and said, "you're trying to break people out of inadequacy, aren't you?" Without missing a beat, he responded, "now you get it." How is home created in a county known for white cultural possessiveness and southern honor? More, how does one keep a theater alive, as well as incrementally change the historically oppressive conditions for populations of color in a county known for reactive racial violence? In a short but rather reductive sense, SSTT brings scripted plays that are 
highly inclusive, and that are 'safe' enough to provide the proverbial mirror for critical learning ... by recruiting others to build safe places of diversity and intimacy. The President of SSTT puts this effort a little differently: "I don't mind being dangerous if I get to pick the weapon. You understand what I mean? I'm not wild about guns, but a knife will allow me a certain measure of distance that I can keep ... The fact that we are here, and we are a theater" (President of SSTT, personal communication).

In Water County, one can still find old Florida - the areas untouched by man-if one knows where to look. But there are shadows lingering that sink into the skin, and into the soul, deeper than the shade of the oak trees hanging overhead. When you drive into Water County, a billboard with imposing white lettering on a blank black background states, "[Water County] loves Jesus." It is a curious mixture of southern hospitality and hostility, like as if it says visitors are expected to be Christian. The further one drives into the county, the more Trump political signs litter the yards of neighborhoods (sometimes next to a rebel flag). These are a few of the cultural symbols that emanate an ownership of the land, and in this county, the owners are white and prefer to keep it that way. When the President and I would venture for set design materials to the local Habitat for Humanity and Walmart, I could feel the tingles of eyes running up my spin asking curiously, if not downright invasively, "what are you two doing together?" I'm a white bisexual Jew covered in tattoos, and the President is a black gay man known for his new theater. Eyes, I learned quickly, can speak (scream) volumes in this county. The President moved from the county years ago to further his craft in New York, and then came back to be close to family and eventually start the theater. He disclosed how the quivers of fear that run up his spine are something he never felt in New York. He seeks to expand the home of his theater with as many as he can regardless of who they are. I once watched him intimately coach a local white male wearing a shirt with the words 'All Lives Matter' inscribed on the American flag on how to act, all without batting an eye.

I was at SSTT primarily to assist as a stage manager, but over time I found myself in an acting role. I was playing a recently divorced sheriff struggling to keep the white male elites of an exurb from creating a militia to drive out their new blue-collar neighbor (a task my character ultimately fails in preventing). The entirety of the cast was white, but it was for a reason. The narrative of the story was a representation of intra-white classism, elitism, misogyny, and violence. There was to be a mirror play of an entirely Black cast performing a narrative of intra-Black classism, elitism, misogyny, and violence (the same play performed by differing races). However, the President was not able to put together a Black cast despite mountains of time and labor. It is not that Black actors and actresses don't exist here ... it is because of the county's reputation. It was because of fear. The goal was to have the two casts and stories be told back-to-back over six performances (each would have been performed 3 times), which would allow for comparative intra-racial storytelling to be performed to an inter-racial local audience.

"I thought, wouldn't it be beautiful to do both of those plays and spread them out through a performance period? So that the people who are in [script name 1] can watch those in [script name 2] and vice versa and see what each is bringing to the table. Better their understanding of it. But also to have some talk backs with the audience, and say what did you think about this one versus that one? What does it say about Black-White relations? Not in the sense that they work together, but in their own little groups. What is the class thing here that we are looking at? What is a class outsider?" (President of SSTT, personal communication)

Nonetheless, the all-white cast, me included, performed six nights after three months of rehearsal. In consequence, the majority of the audience members were white. In hindsight, I believe the effort to attempt such an endeavor speaks volumes on the nature of the theater. It is frustrating that the full project could not have been completed, for it could have unveiled critical race issues relating to white classism and ideological supremacy [53].

Regardless, generating trust is not easy amongst strangers ... even those of the same race. Scripted performances that last over an hour are incredibly demanding, complex, and full of nuanced detail that 
can drown the mind. They are ensembles of emotion, timing, memory, and embodiment of character. For example, I played the conscious and shy sheriff of the exurb, which required the performance of numerous confrontations between myself and the main antagonist of the story. My aesthetic role as the conscious sheriff was to provide a sensitized mirror to the conspiring violence being generated by the elite white men. I am towering at a whopping five feet nine inches, and the main antagonist is six feet four inches, so it took trust and courage to 'hold my ground' as the main actor screamed in my face in front of an audience.

\section{Doing Community-Based Theater 'Work' ... the Activation of Abundance}

Acting a complex role/story forces one to pull personal experiences out to channel the being of the character for an audience. This is hard enough, let alone the learning of lines, learning/interpreting the meaning of the lines, learning the movements of characters on stage (blocking), and learning the timing of scene transitions with people you have known only for a short time. All of these aspects are the creation of places and experiences from memory-based praxes that manipulate emotion, body language, and language itself for the production. The work required the navigation of trust, vulnerability, and personal boundaries. However, through the work, closeness through collaborative dialogue was indeed nurtured. This roller coaster of learning, producing, and performing this craft together was the experiment of CBT in both counties. However, the flow that produces the embodiment of a fictional world to transmit culturally salient messages to the local county only truly became sensitized when boundaries between strangers became relational collaboration between fellow actors and crew. As such, strangers of the counties became co-creators of complex meanings, thus creating a production of community-based performative art mirroring and contrasting diverse realities.

SSTT and AT are seeking to instill salient experiences inspired by local life through their creative praxes of performed storytelling. Theater here is a modelling and communication process of imaging a/the world - real and/or imaginary - in the space of theater. Theater making in both communities is a shared creative endeavor for participants looking out at their local counties, but also jointly within themselves. The theaters, with the help of the participants, crafted scenes that assisted in transitioning participants and audiences from a pre-performance state to a post-performance place. The space of the theaters, as a material technical function, served as a palette for creative imagining to bring stories to life beyond the page, beyond the recollection of memory, and through shared/divergent interpretations of the lifeworlds of the performed stories. The role of the theater as an organization, was to facilitate this process by supporting active agency between participants to sculpt, craft, practice, and ultimately perform a story that local audiences could connect with as an imaginary conjuring (a conjuring that is not detached from local life/society). For example, the recreation of a church setting at AT to bring grace to hardship, or the recreation of upscale neighborhood with powerful connotations of class and social strife at SSTT.

CBT in both cases also served as a hodological (way finding) function [19] of transitioning pre-individuated selves through a socially interdependent process to more experientially 'broken open' spaces. Collaborative interdependence did not reduce individuality, if anything it strengthened the individuals' sense of personal being in the process of co-creative imaging. This process is particularly salient as participants take lines of text to build characters and scenes or interpret the meaning of oral stories as if they were their own to perform on stage. CBTs are cultural apparatuses built through dialogic and performative persons communicating a subjective set of messages about the world as they know it [11]. These worlds must be navigated jointly between participants, and theater as method supports and intimately engages cultural differences as a hodological praxis. "The potential multiplicity, polyvalence, and redundancy of actual and narrative paths and trails they [participants] open up allow for adaptivity and new connections, thus growth and change in our physical and cognitive navigation patterns" [3] (p. 4). As such, deeper interpersonal behavior was cultivated between participants whilst they simultaneously navigated the convergence of lifeworlds as a critical function of the creative praxes. For example, the main antagonist during SSTT's performance used 
past lived experiences from alcoholic family members to help fuel the anger of his alcoholic character, and doing helped him more in the process of individuation, personally and socially. "It did help me understand who I am more, well a part of me more, and who I really am. After the play it brought clarity" (Theater participant, personal communication).

Individuals (participants and audiences) are embedded within cultural contexts whilst also representing their own complex cultural identity $[54,55]$. Conceptualized in Figure 1, within a shared space, agency across theater participants is communicatively navigated to create, embody, and portray multifaceted narratives with the assistance of theater architecture (stage, lighting, sounds/music, props, costumes) to the localized cultural participation of audience members [3]. Through such processes, more vulnerable forms of communication are harnessed to deepen, signify, and enhance the lived experience of performance. For example, the main actor of SSTT's performance is a singer song writer that used to perform in Tennessee before moving to Water County. As an introduction to the performance, he sang live, on our self-made set, his own southern blues song to manifest the setting and tone necessary to engage the actors and audience in the southern culture of Water County.

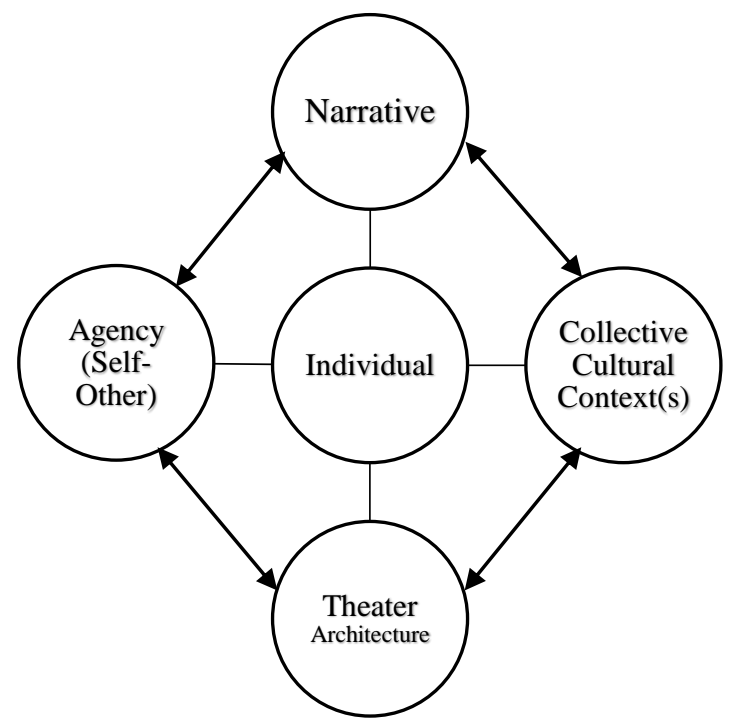

Figure 1. Individuation and Emergence in Community-Based Theater.

The personalized narratives that are actively created, and performed, aim to shift the manner in which local citizens experience themselves with each other. These cultivated lived experiences change awareness of participants from stranger, to acquaintance, to neighbor in an endeavor to recalibrate the lived experience of 'community.' The essence of this process is beautifully summarized by Gumbrecht [56] regarding the transition away from fixed, unaltering, and power-driven Cartesian reality,

"In the process of Modernization, the dream of becoming perfectly "Cartesian" has thus been so perfectly fulfilled that we seem to have lost any material concreteness to hold onto ... more so, perhaps, than we are to existentially afford. For our bodies have been reduced to a mere energy base for our minds, struggling to find pleasure and a dignity of their own." (p. 208)

The pivot away from Modernization as explicated by Gumbrecht [56], and as embodied by CBT, constitutes a process that effectively engages a comprehensive person, within the present, to change the conditions of communication and thus change the potential forms of interaction between self, other and world. This imaginary and communicatively interdependent process creates opportunities to engage the body and mind in action and change across diverse people and environments. The performative and co-constructive process further reconstitutes memory and history in the present as an emergent act 
of co-creation across participants. Lastly, the reconstitution of memory and history within this creative praxis did not synthesize history in the present to exclude the implications of history on the present. Rather, the creative imaginary, but nevertheless interdependent praxes, made 'space' for history to play an embodied experience within the dialogical place of the theaters.

Purposefully created characters, scripted or improvised, can be considered an 'incarnation' of persons or beings through which theater participants can experience themselves and each other [57]. Further, as an embodied incarnation that is thus performed, this incarnated being is inseparable from the citizen that is doing the embodying. The purposefully entangled character that is built upon a presence of interdependent participants and audiences is further inseparable from the cultural contexts and geographies of the performance's location. The communicative process of incarnation is described by Brummans [57],

"By defining incarnation as the communicative practices (i.e., the use of words and sounds, gestures, turns of talk, objects, etc. in everyday interactions) through which people transfer agencies or powers to material things or persons in order to concretize their connections and identifications with more or less abstract, ineffable/indefinable, immaterial/metaphysical, or absent/invisible/imperceptible being or concepts (values, principles, ideals, identities, etc.)." (p. 196)

Within a narratively driven performance, all material items on stage have been given meaning through the transfer of agency onto them by the participants as well as the audience's interpretations of the productions. As such, the process by which characters and material items are 'incarnated' to create an affective environment, is thus manifested through the performance of the participants' interaction with each other both as actors/actresses and as local citizens. The overall purpose of this communicative interdependency [58] is the creation of lived experiences that are transmitted through and built upon complex co-constructed meanings, characters, and settings (see Figure 2). Thus, incarnation is a reconceptualization of abundance to physicalize the myriad of personal and material interactions occurring in the CBTs that assist in the translation of storytelling into communication modalities that instantiate interdependent relationships over time and space.

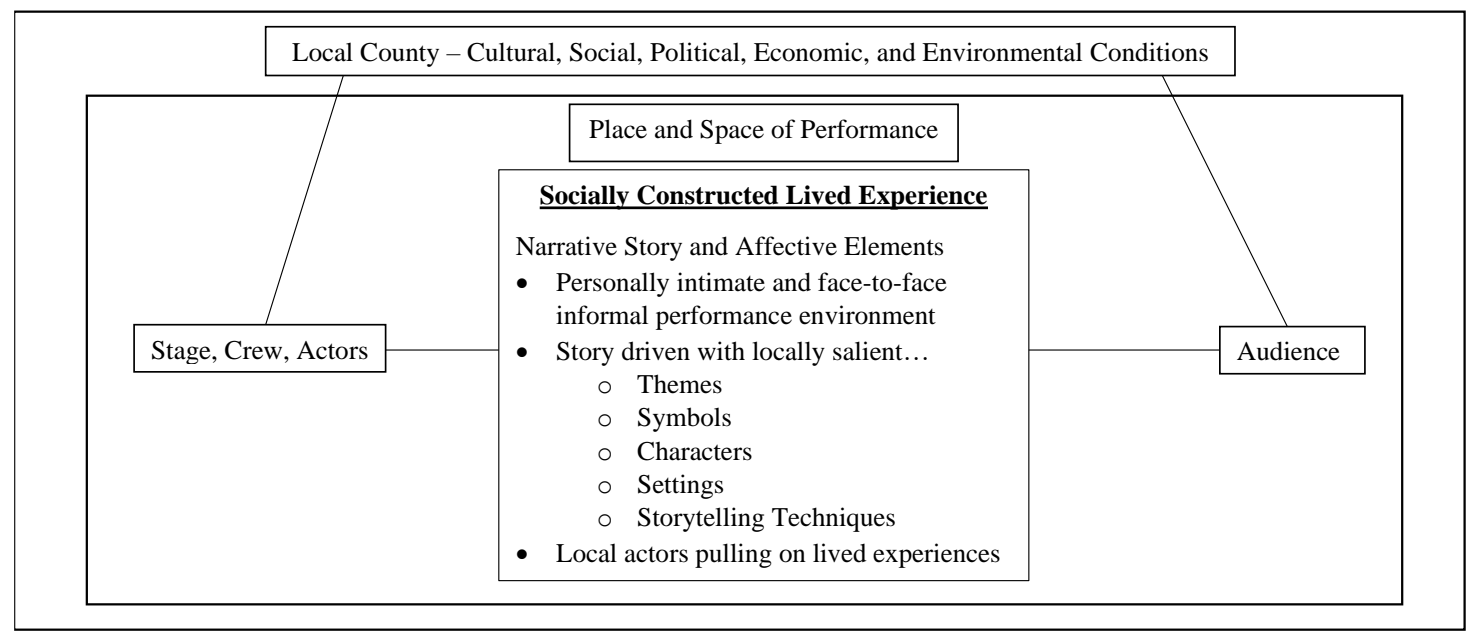

Figure 2. The Hall of Local Mirrors and Meanings.

Beyond the creation of meanings, there are further implications to the communicative process of incarnation. It would be wrong, at least within this work, to label the creation of an affective environment as a social field upon which social interaction stood. Rather, interaction between participants and audiences deepened due to the dialogic function of the constructed narratives that drove a multiplicity of interpretations, not a purity of artificial objects, derived from the lived performative experiences $[3,34,59]$. Even though the enactments manifested are in many ways an act of 
ventriloquism of local life and people, the productions nonetheless are deeply entangled with personal identity, culture, space, and place. This entangled irreducibility is derived from purposefully refuting the sedimentation of lame explanations of local life to develop further discussions on the complexity of living, and at times surviving [60]. As a dialogic process that is narratively driven, performative incarnation is the foreground that presents itself upon the physical presence of the local background. Inevitably, this duality and distinction buckles under the entwined form of communication that the narratives/performances have with the audiences and local communities. In both cases, this process of trans-positioning, a layering of a created narrative on top and through everyday life, provided a place through which citizens could focus discussions both privately/internally and with each other.

The performances in both cases were a complex augmentation of personal boundaries between participants and audiences, but as well as the boundaries between local life and the narratives of the performances. Acting as sites of cultural renewal and change [61], the drama of the performances narratively created a deeper social ontological heterogeneity to serve dialogic functions assisting in the creation of relationships between people and the theaters [56]. The broken open spaces within the theaters served as an opportunity for social relationality/collaboration/dialogue beyond the confines of the theaters. In other words, strangers were now in conversation with each other. This complex set of mechanisms deepened relationships between citizens in both counties; AT deepened relationships between people and non-profits to aid in survival and renewal, and SSTT deepened relationships between people to millimetrically-but nevertheless crucially-adjust face-to-face race and class relationships (Table 2 ).

Table 2. Incarnation of New Modes of Being in a Narrative Construction.

\begin{tabular}{l}
\hline \multicolumn{1}{c}{ Intersection of Interpersonal Interaction and Public Performance } \\
\hline $\begin{array}{l}\text { Continuous interaction between individuals through confluences and collisions of individual lifeworlds, both } \\
\text { real and constructed }\end{array}$ \\
\hline Enactment of narrative(s) \\
\hline Local performances \\
\hline Engaged and cultivated social interdependency across participants and audiences \\
\hline
\end{tabular}

\section{Conclusions}

The work of this article sought a deeper investigation on how community-based theater (CBT) in two rural communities function as methods of asset-based community development (ABCD) whilst simultaneously aligning themselves with an inclusive and critical orientation to complex socio-cultural realities. Through deep participatory research — constructivist embodiment and semi-structured interviewing - this work specifically sought to bring to light how interdependency and co-creation of community performances shift how participants experience themselves, each other, and their larger 'community.' The purpose of examining how these CBTs were functioning simultaneously as cultural apparatuses and places of ABCD was to extend beyond normative conceptualizations of 'abundance' [4]. More, the work examined how these CBTs were functioning as places of ABCD within a more realized and described context.

Sitting in the Shade Together Theater (SSTT) and Appalachian Theater (AT) differ in methodology in some ways, however the overall intent and structure of their work is nonetheless very similar. SSTT in a divided socio-cultural landscape utilizes co-constructed scripted performances to engage participants and audiences in subject matter that reflects and models the divided cultural landscape of Water County. As such, the cultivated interdependency across participants in the scripted environment of SSTT provides a framework through which participants and audiences disclose their interpretations and lived experiences in discursive and dialogic actions to 'break open' structural issues in the county through storytelling. Similarly, at AT, the improvisational performances do not have the same 'rigor' as a scripted performance but are nevertheless designed to welcome participants and audiences to 
engage in a co-created performances of real stories from the county. AT thus endeavors for the creation of belonging and acknowledgement in a county that has a brutal history of poverty, cultural shame, corrupt politicians, and extractive industries.

Through the communicative behavioral complexity of public performance and storytelling, the co-constructed performances and narratives at both theaters simultaneously act as a hodological function to organize and frame discourses, as well as permit historically derived lived experiences to be situated in the present as an act of 'incarnation' [57]. As cultural apparatuses [3], the theaters and the generated experiences and discourses are thus intentional actions of co-constructed opportunity for participants to reconstruct socio-cultural relationships within the theaters. These theaters are making the effort to reconsider how individuals relate to one another, at least within face-to-face contexts, to reclaim and renew space and place through dialogue. Every community has a past, and often these pasts are riddled with the legacies and vestiges of ideology, violence, and trauma-but also hope. From the standpoint of ABCD, AT and SSTT use these tainted soils of history to help recalibrate social relationships for purposeful outcomes in the present, whether these outcomes be the augmentation of a frictional and violent socio-cultural landscape (SSTT), or the creation of cultural renewal for survival and connection (AT).

$A B C D$ through its formative years did not explicitly align itself with social justice frameworks to elucidate its intentions, processes, and goals relating to vulnerable populations and populations of color [62-64]. Recently, however, the Asset-Based Community Development Institute (ABCDI) has released a public statement admitting that without this explicit differentiation and alignment with social justice, it has indeed "been complicit in the systems [they] aim to transform" [65]. This differentiation towards more scrupulously examining why and how vulnerable populations and populations of color are oppressed creates greater opportunity to assist in the dismantlement of longstanding structural inequities. Nonetheless, this progressive step further requires integral behavioral and theoretical changes in how $\mathrm{ABCD}$ has in part served as a tool of inoculation [20] through passive omission and romanticized views of 'community'. I would encourage the Asset-Based Community Development Institute to continue their revised positioning to more clearly conceptualize how ABCD is a method that can be used to address systems of racism and oppression, and that as a method ABCD emerged as a method due to large scale structural inequities born from racism and oppression.

Funding: This research received no external funding.

Conflicts of Interest: The author declares no conflict of interest.

\section{References}

1. Rivers, N.A.; Ryan, P.W. Ecological, Pedagogical, Public Rhetoric. Coll. Compos. Commun. 2011, 2, $187-218$.

2. Hutchins, E. Cognition in the Wild, Revised ed.; Mass: Cambridge, UK, 1995.

3. Norman, S.J. Theatre as an Art of Emergence and Individuation. Archit. Theory Rev. 2012, 17, 117-133.

4. McKnight, J.; Peter, B. The Abundant Community: Awakening the Power of Families and Neighborhoods; Berrett-Koehler Publishers: Oakland, CA, USA, 2011.

5. Scharmer, C.O. Uncovering the Blind Spot of Leadership. Lead. Lead. 2008, 47, 52-59. [CrossRef]

6. Kretzmann, J.; John, P.M. Assets-Based Community Development. Natl. Civ. Rev. 1996, 85, 23-29. [CrossRef]

7. Garven, F.; Jennifer, M.; Lisa, P. Asset-Based Approaches: Their Rise, Role and Reality, New ed.; Dunedin Academic Press: Edinburgh, UK, 2016.

8. Mathie, A.; Jenny, C.; Katherine, G. Asset-Based and Citizen-Led Development: Using a Diffracted Power Lens to Analyze the Possibilities and Challenges. Prog. Dev. Stud. 2017, 17, 54-66. [CrossRef]

9. Johnson, A.K.; Michael, S. Asset-Based Social Welfare Policy: Homeownership for the Poor. J. Sociol. Soc. Welf. 1992, 19, 65.

10. MacLeod, M.A.; Akwugo, E. Neoliberalism With a Community Face? A Critical Analysis of Asset-Based Community Development in Scotland. J. Community Pract. 2014, 22, 430-450. [CrossRef]

11. Cohen-Cruz, J. Local Acts: Community-Based Performance in the United States; Rutgers University Press: New Brunswick, NJ, USA, 2005. 
12. Haedicke, S.C.; Nellhaus, T. (Eds.) Performing Democracy: International Perspectives on Urban Community-Based Performance; University of Michigan Press: Ann Arbor, MI, USA, 2001.

13. Seifert, U.; Jin, H.K. Embodiment and Agency: Towards an Aesthetics of Interactive Performativity. In Proceedings of the 4th Sound and Music, Lefkada, Greece, 11-13 July 2007.

14. Baol, A. Theatre of the Oppressed; Pluto Press: London, UK, 2000.

15. Freire, P. Pedagogy of the Oppressed, 30th Anniversary ed.; Continuum: New York, NY, USA, 2000.

16. Leonard, R.H.; Ann, K. Performing Communities: Grassroots Ensemble Theaters Deeply Rooted in Eight U.S. Communities; New Village Press: New York, NY, USA, 2006.

17. Geer, R.O.; Jules, C.; Melissa, B.; Juanita, B.; David, I. Story Bridge.: From Alienation to Community Action; CreateSpace Independent Publishing Platform: Scotts Valley, CA, USA, 2012.

18. Geer, R.O.; Wei, Q. Open Circle: Story Arts and the Reinvention of Community, 1st ed.; CreateSpace Independent Publishing Platform: Scotts Valley, CA, USA, 2017.

19. Turnbull, D. Maps Narratives and Trails: Performativity, Hodology and Distributed Knowledges in Complex Adaptive Systems-An Approach to Emergent Mapping. Geogr. Res. 2007, 45, 140-149. [CrossRef]

20. Sandoval, C. Methodology of the Oppressed; University of Minnesota Press: Minneapolis, MN, USA, 2000.

21. Emejulu, A. Re-Theorizing Feminist Community Development: Towards a Radical Democratic Citizenship. Community Dev. J. 2011, 46, 378-390. [CrossRef]

22. Wilson, P.A. The Heart of Community Engagement: Practitioner Stories from Across the Globe; Routledge: London, UK, 2019.

23. Young, I.M. The Ideal of Community and the Politics of Difference. Soc. Theory Pract. 1986, 12, 1-26. [CrossRef]

24. Johnson, N. The Role of Self and Emotion within Qualitative Sensitive Research: A Reflective Account. Enquire 2009, 2, 23-50.

25. Denzin, N.K.; Yvonna, S.L. The Landscape of Qualitative Research, 3rd ed.; Sage Publications: New York, NY, USA, 2008.

26. Kincheloe, J.L.; McLaren, P.; Steinberg, S.R. Critical Pedagogy and Qualitative Research. In The Landscape of Qualitative Research, 4th ed.; Sage: Thousand Oaks, CA, USA, 2011; pp. 339-370.

27. Durkheim, E. The Elementary Forms of Religious Life, 1st ed.; Mark, S.C., Carol, C., Eds.; Oxford University Press: New York, NY, USA, 2008.

28. Brow, J. Notes on Community, Hegemony, and the Uses of the Past. Anthropol. Q. 1990, 63, 1-6.

29. Rescher, N. Pluralism: Against the Demand for Consensus; Oxford University Press: New York, NY, USA, 1993.

30. Wiesenfeld, E. The Concept of 'We': A Community Social Psychology Myth? J. Community Psychol. 1996, 24, 337-346. [CrossRef]

31. Block, P. Community: The Structure of Belonging; Berrett-Koehler Publishers: Oakland, CA, USA, 2009.

32. Clarke, A.; Allan, J. Power and Hegemony within a Community Festival. Int. J. Event Festiv. Manag. 2011, 2, 7-19. [CrossRef]

33. Jepson, A.; Alan, C. Events and Community Development; Cabi: Wallingford, UK, 2013; pp. 6-17.

34. Adorno, T. Negative Dialects; Routledge: London, UK, 2003.

35. McKenzie, J.F.; Robert, R.P.; Denise, S. An Introduction to Community \& Public Health, 9th ed.; Jones \& Bartlett Learning: Burlington, MA, USA, 2016.

36. Giardina, M.D.; Joshua, I.N. Cultural Studies: Performative Imperatives and Bodily Articulations. In The Sage Handbook of Qualitative Research; Sage: Thousand Oaks, CA, USA, 2011; pp. 179-194.

37. Langdridge, D.; Jacqui, G.; Jamie, L. Art as a Pathway to Impact: Understanding the Affective Experience of Public Engagement with Film. Sociol. Rev. 2019, 67, 585-601. [CrossRef]

38. Stratton, M.T.; Kass, D.S.; Rotenberry, P.F. Affective Events Theater: Creating Teaching Moments from Film and Television to Explore Emotions in the Workplace. J. Acad. Bus. Educ. 2011, 12, 259-281.

39. Wiener, D.J. Rehearsals for Growth: Applying Improvisational Theater Games to Relationship Therapy. In Beyond Talk Therapy: Using Movement and Expressive Techniques in Clinical Practice; American Psychological Association: Washington, DC, USA, 1999.

40. Grossberg, L. Bringing It All Back Home: Essays on Cultural Studies; Duke University Press: Durham, NC, USA, 1997.

41. Strauble, I. Entangled in the Eurocentric Order of Knowledge: Why Psychology Is Difficult to Decolonise. PhD dissertation, University of the Western Cape, Cape Town, South Africa, 2005. 
42. Horton, M.; Paulo, F. We Make the Road by Walking: Conversations on Education and Social Change; Brenda, B., John, G., John, P.R., Eds.; Temple University Press: Philadelphia, PA, USA, 1990.

43. Connor, J.A.; Stephanie, K.-T.; Diane, V.-K. The Role of Nonprofit Management Support Organizations in Sustaining Community Collaborations. Nonprofit Manag. Leadersh. 1999, 10, 127-136. [CrossRef]

44. Lawrence, R.L. Powerful Feelings: Exploring the Affective Domain of Informal and Arts-Based Learning. New Dir. Adult Contin. Educ. 2008, 120, 65-77. [CrossRef]

45. Nel, H. A comparison between the asset-oriented and needs-based community development approaches in terms of systems changes. Practice 2018, 30, 33-52. [CrossRef]

46. Lam, B.; Theodore, Z.; Mihaela, K.; Jea, H.N. Unearth hidden assets through community co-design and co-production. Des. J. 2017, 20, S3601-S3610. [CrossRef]

47. Duffly, C.; Ming, T. Farms and Fables: Cultivating Difference in Community-based Theatre. Theatre Top. 2016, 26, 283-293. [CrossRef]

48. Feldhoff, T. Asset-based community development in the energy sector: Energy and regional policy lessons from community power in Japan. Int. Plan. Stud. 2016, 21, 261-277. [CrossRef]

49. Liebenberg, L.; Daphne, H.-M. Community development approaches in response to neoliberalism. Routledge Handb. Glob. Child. Welf. 2017, 47, 1-17.

50. Forenza, B. Sustained community theater participation as civil society involvement. Nonprofit Volunt. Sect. Q. 2017, 42, 549-566. [CrossRef]

51. Forrester, G.; Judith, K.; Penny, V.; Mike, O. Schools as community assets: An exploration of the merits of an Asset-Based Community Development (ABCD) approach. Educ. Rev. 2018, 72, 1-16. [CrossRef]

52. Kuftinec, S.A. "Do you need help?": Dialogics of Change in Community-Based Theatre. Theatre Surv. 2016, 57, 419-423. [CrossRef]

53. Dickinson, E. Addressing Environmental Racism through Storytelling: Toward an Environmental Justice Narrative Framework. Commun. Cult. Crit. 2012, 5, 57-74. [CrossRef]

54. Nelson, A.; Brian, A. Storytelling for Empowerment: Decreasing At-Risk Youth's Alcohol and Marijuana Use. J. Prim. Prev. 2003, 24, 169-180. [CrossRef]

55. Sandercock, L. From the Campfire to the Computer: An Epistemology of Multiplicity and the Story Turn in Planning. In Multimedia Explorations in Urban. Policy and Planning; Springer: Dordrecht, The Netherlands, 2010.

56. Gumbrecht, H.U. Incarnation, Now: Five Brief Thoughts and a Non-Conclusive Ending. Commun. Crit. Cult. Stud. 2011, 8, 207-213. [CrossRef]

57. Brummans, B.H. What Goes down Must Come up: Communication as Incarnation and Transcension. Commun. Crit. Cult. Stud. 2011, 8, 194-200. [CrossRef]

58. Caughlin, J.P.; Liesel, L.S. A Communicative Interdependence Perspective of Close Relationships: The Connections Between Mediated and Unmediated Interactions Matter. J. Commun. 2013, 63, 873-893. [CrossRef]

59. Spatz, B. Embodied Research: A Methodology. Liminalities A J. Perform. Stud. 2017, 13, 1-31.

60. Buber, M. I and Thou (W. Kaufmann, Trans.); Charles Scribner's Sons: New York, NY, USA, 1970.

61. Barad, K. Posthumanist Performativity: Toward an Understanding of How Matter Comes to Matter. Signs J. Women Cult. Soc. 2003, 28, 801-831. [CrossRef]

62. Dwyer-Voss, R.; Indigo, B. Let's Get Explicit: Social Justice in Asset Based Community Development; Asset-Based Community Development Institute: Chicago, IL, USA, 2019.

63. Garcia, I.; Andrea, G.-C.; Deirdre, P. Planning With Diverse Communities. Planning Advisory Service (PAS) Report; American Planning Association: Chicago, IL, USA, 2019.

64. Diers, J. Social Justice Is Not As Easy As ABCD | Neighbor Power Blog. Available online: http://blog.neighborpower.org/uncategorized/social-justice-is-not-as-easy-as-abcd/\#: \{\}:text=In\% 20fact $\% 2$ C $\%$ 20unless $\% 20$ an $\% 20$ ABCD, potential\%20to $\% 20$ exacerbate $\% 20$ current $\% 20$ inequities (accessed on 17 July 2020).

65. Asset Based Community Development Institute Policy Statement on Anti-Racism. Available online: https://resources.depaul.edu/abcd-institute/Pages/default.aspx (accessed on 17 July 2020).

(C) 2020 by the author. Licensee MDPI, Basel, Switzerland. This article is an open access article distributed under the terms and conditions of the Creative Commons Attribution (CC BY) license (http://creativecommons.org/licenses/by/4.0/). 